\title{
Assessment of Genetic Variability in Prolactin Gene and Its Impact on Milk Composition in Bos indicus Cattle
}

\author{
Vijay Kumar Agrawal ${ }^{1}$, Gyanchand Gahlot ${ }^{1}$, Rajeev Joshi ${ }^{1}$, \\ Govind Singh Dhakad ${ }^{1}$ and Sonal Thakur ${ }^{2}$ \\ ${ }^{1}$ Department of Animal Genetics and Breeding, Veterinary College, Bikaner (Raj.), India \\ ${ }^{2}$ Department of Animal Husbandry, Govt. of Rajasthan, India \\ *Corresponding author
}

A B S T R A C T

\begin{tabular}{l} 
Ke y w o r d s \\
Prolactin, RFLP, \\
Sequence \\
polymorphism, \\
Milk composition \\
\hline Article Info \\
\hline $\begin{array}{l}\text { Accepted: } \\
18 \text { May } 2020 \\
\text { Available Online: } \\
\text { 10 June } 2020\end{array}$ \\
\hline
\end{tabular}

The candidate gene effect of prolactin gene $(P R L)$ on milk traits suggests the important role of genetic variability in prolactin gene on milk composition parameters. Therefore the present study was conducted to explore the genetic variation in PRL gene through sequence based RFLP marker approach and to observe their association with milk composition in three Bos indicus cattle breeds (Rathi, Sahiwal and Kankrej). Genomic DNA was extracted from blood samples collected from 225 randomly selected milking cows maintained at Livestock Research Stations at Bikaner. A $156 \mathrm{bp}$ fragment length of $P R L$ gene was amplified through species specific primer. Milk samples from respective animals were analyzed on three different occasions for estimation of different constituents of milk. RFLP marker detected the presence of two genotypes; $G G$ and $A G$ in each breed. Sequence analysis identified an overall four nucleotide substitutions found to be responsible for genetic variation in $P R L$ gene. Association analysis revealed the presence of significant association between genetic variability in prolactin gene and milk protein content with no impact on other milk constituents. The present study concluded that heterozygotes genotypes for $P R L$ exon-3 region were favored in studied Bos indicus breeds to produce milk containing higher amount of protein.

\section{Introduction}

India is homeland and origin place of many elite cattle breeds of the world and possesses around 40 well recognized Bos indicus breeds of cattle (Anonymous, 2013) which holds great promise and potential for milk production in addition to their exemplary adaptability to tropical climate. The effective assessment of genetic variability in genes affecting the physiological pathways of milk composition traits (Agrawal et al., 2018) and incorporation of this genotypic information as fixed factor in estimation of breeding value could significantly improve the selection responses and potential values of the indigenous cattle genetic resources (Mohammed et al., 2015). Newer breeding goals especially on milk composition traits have recently gained importance following 
the demands of a healthier human diet (Krovvidi et al., 2013).

The assessment of genetic variability in genes affecting milk traits in indigenous cattle could establish their association with lactation performance (Agrawal et al., 2017). The candidate gene approach (El-Magd et al., 2014) have detected bovine prolactin (bPRL) gene as one of the potential candidate gene that have significant impact on milk composition traits in dairy cattle (Komisarek and Dorynek, 2009) due to their positional role on chromosome 23 at $43 \mathrm{cM}$, close to the quantitative trait loci region (QTLs) of 36, 41, and $42 \mathrm{cM}$ (Bennewitz et al., 2004). The prolactin gene invariably affects growth and development of mammary gland (mammogenesis), synthesis of milk (lactogenesis) and maintenance of milk secretion (galactopoiesis) (Dong et al., 2013). The indirect effect of prolactin gene on milk production traits occurs through its modulatory role on thermoregulatory mechanisms during hot climates (Alamar, 2011) and regulatory role in calcium homeostasis through enhanced intestinal calcium absorption (Charoenphandhu and Krishnamra, 2007). In addition, transcript product of prolactin gene is known to initiate a signaling cascade that activates the transcription of a number of genes, including expression of milk protein, lactose and lipid genes (Othman et al., 2011) via Janus kinases/signal transducers and activators of transcription (JAK STATs) signal transduction pathway (Hu et al., 2009) through binding with prolactin receptor gene (PRLR).

As most of the earlier studies have reported polymorphism within the $b P R L$ gene on the basis of restriction fragment length polymorphism (RFLP) without explaining the nature and locations of nucleotide substitutions, the present investigation was planned to comprehensively detect the genetic variability in prolactin gene through sequence based RFLP marker approach and its impact on milk composition in three different Bos indicus cattle.

\section{Materials and Methods}

Selection of Animals: Apparently healthy and mastitis free 225 milking Bos indicus cows with 120 days lactation were selected at random from pure breeding population of Rathi ( $n=75)$, Sahiwal $(n=75)$ and Kankrej $(n=75)$ maintained at Livestock Research Stations of Rajasthan University of Veterinary and Animals Sciences, Bikaner (Rajasthan) under similar managemental and feeding conditions in a grid position of $28.02^{\circ} \mathrm{N}$ and $73.31^{\circ} \mathrm{E}$ with mean annual rainfall of 277.55 $\mathrm{mm}$.

Extraction of Genomic DNA and PCR Amplification: Genomic DNA was extracted from $2 \mathrm{ml}$ whole blood collected from jugular vein in an Ethylene Diamine Tetra Acetic acid (EDTA) containing sterile vacutainer tube through Genomic DNA Isolation Kit (Himedia Pvt Ltd) as per manufacturer's protocols. Nano-drop spectrophotometry and $0.8 \%$ agarose electrophoresis was carried out to assess the purity (OD ratio 260/280) and concentration $(\mathrm{ng} / \mu \mathrm{l})$ of extracted genomic DNA. A 156-bp fragment of exon-3 of $P R L$ gene was amplified by polymerase chain reaction (PCR) in a final reaction volume of $25 \mu 1$ with reaction mixture of $5 \mathrm{X}$ PCR buffer $(5 \mu \mathrm{l}), 1.5 \mathrm{mM} \mathrm{MgCl} 2(3 \mu \mathrm{l}), 10 \mathrm{Mm}$ dNTP's mix $(1 \mu \mathrm{l})$, forward primer $70 \mathrm{pmol} / \mu \mathrm{l}(1 \mu \mathrm{l})$, reverse primer $70 \mathrm{pmol} / \mu \mathrm{l}(1 \mu \mathrm{l})$, genomic DNA $25 \mathrm{ng} / \mu \mathrm{l}(4 \mu \mathrm{l})$, Taq DNA polymerase $5 \mathrm{U} / \mu \mathrm{l}(0.2 \mu \mathrm{l})$ and DNAase free water $(10.8 \mu \mathrm{l})$. A set of common forward and reverse primer pair (F5'CGAGTCCTTATGAGCTTGATTCTT-3'; R3'-GCCTTCCAGAAGTCGTTTGTTTTC5') was constructed as suggested by Mitra et 
al., (1995) for indigenous cattle. Amplification was performed in a thermal cycler with following program; after an initial denaturation step at $95^{\circ} \mathrm{C}$ for $5 \mathrm{~min}, 35$ cycles were programmed as follows: $95^{\circ} \mathrm{C}$ for $45 \mathrm{~s}$, $59^{\circ} \mathrm{C}$ for $45 \mathrm{~s}, 72{ }^{\circ} \mathrm{C}$ for $60 \mathrm{~s}$ and final extension at $72^{\circ} \mathrm{C}$ for $10 \mathrm{~min}$. The amplified DNA fragments were stained and visualized on $1.5 \%$ agarose gel under Gel Documentation System.

Assessment of Genetic variability in $b P R L$ gene: The initial screening for polymorphism at specified nucleotide position was carried out through RFLP method. The 156 bp amplicons of exon-3 region of PRL gene was digested in reaction mixture containing $10 \mathrm{X}$ buffer $(2 \mu \mathrm{l})$, amplified product $(10 \mu \mathrm{l})$, restriction enzyme Rsa I 10 units $(1 \mu \mathrm{l})$ and nuclease free water $(17 \mu \mathrm{l})$ at $37^{\circ} \mathrm{C}$ for $6 \mathrm{hr}$ in water bath and electrophoresed on $8 \%$ polyacrylamide gel at $120 \mathrm{~V}$ for the probable nucleotide substitution at GTAC recognition site. The gels were stained with $1 \%$ ethidium bromide solution and visualized with under UV light and documented by gel documentation system. The determination of prolactin genotypes was carried out on the basis of number and size of the digested fragments: ( $G G 156 \mathrm{bp}), A G$ (156 bp, $82 \mathrm{bp}$, $74 \mathrm{bp})$ and $A A(82 \mathrm{bp}, 74 \mathrm{bp})$ (Udina et al., 2001).

At least five representative PCR products under each electrophoresed RFLP patterns in each breed were purified through Exosap method and sequenced in both directions in an ABI PRISM 377 DNA Sequencer (Applied Biosystems, Foster City, CA, USA) through Sanger dideoxy chain termination method for sequence analysis and SNP's detection. The raw sequences were analyzed with Chromas 1.45 (http://www.technelysium.co.au) software for the detection of sequencing anomaly and forward and reverse sequence of each gene fragment was assembled against the most closely related reference sequence through BLAST algorithms http://www.ncbi.nlm.nih.gov/BLAST) and Bioedit Sequence Alignment Editor (ver. 7.0.5.3) software. Multiple sequence alignment (MSA) for sequenced region of $P R L$ gene was carried out through Clustal W software in order to detect the precise location of SNP's. Generated sequences were submitted to National Center for Biotechnology Information (NCBI) GenBank database for assignment of accession numbers.

Collection and Analysis of Milk Samples: About $100 \mathrm{ml}$ was collected from each animal during mid milking stage in clean, dry, grease free and labeled milk collection vials on the same test day of each month for three consecutive months. Animals in terminal stage of lactation were not selected for milk collection. The collected milk samples were transported under ice to Milk Analysis Laboratory of Uttari Rajasthan Milk Union Limited (URMUL), Bikaner (Rajasthan) for the analysis of different milk constituents through Automated Milkoscan Tester (Bentley Instruments Inc., Chaska, USA).

Impact of Genetic Variability on Milk Composition Parameters: The differences among genotypes within breed were tested for significance of association with milk composition values using least square method of SPSS ver. 20.0 for Windows (SPSS Inc., Chicago, IL, USA). Statistical analysis was carried out through following general linear model (GLM):

$X_{i j}=\mu+g_{i}+e_{i j}$

where-

$X_{i j}=$ mean observed value of milk performance parameter, $\mu=$ general mean gi= fixed effect of the $i^{\text {th }}$ genotype, $e_{i j}=$ random error, $\mathrm{e}_{\mathrm{ij}} \sim \mathrm{NID}\left(0, \sigma_{\mathrm{e}}{ }^{2}\right)$ 


\section{Results and Discussion}

An integrated approach through RFLP marker in conjunction with sequence analysis as suggested by Alipanah et al., (2007a) was adopted in the present study to detect the genetic variability which could be used as more informative marker for their impact on milk composition traits. The RFLP marker based assessment of genetic variability in 156-bp fragment of $P R L$ gene at $A / G$ SNP position revealed the presence of two genotypes, $G G$ and $A G$ with complete absence of genotypic pattern $A A$ in all the studied Bos indicus cattle breeds (Fig. 1). The allele $A$ was detected in heterozygous form only. The studied breeds revealed similar genetic structures in term of analyzed $A / G$ SNP despite their different origins. Similar restriction patterns using $R s a$ I restriction enzyme were reported by Kumari et al., (2008) in exotic and Zebu cattle, Sacraverty et al., (2008) in Kankrej cattle and Ghasemi et al., (2009) in Montebeliard cows. The genotypic frequency of $G G$ genotype ranged from 0.19 to 0.36 , whereas such frequency for $A G$ genotypic pattern ranged from 0.64 to 0.81 (Table 1). The relatively higher percentage of heterozygotes observed in
Sahiwal breed could be due to over exploitation of pure bred animals of this precious genetic resource (Anonymous, 2013). The $A$ allele of prolactin exon-3 was found to be more prevalent in Sahiwal cattle (0.41) than Rathi (0.36) and Kankrej cattle (0.32).

Similar to present investigation, Aravindakshan et al., (2004) in Vechur cattle and Kumari et al., (2008) in different Bos indicus breeds reported higher frequencies of $A G$ genotypes. An excess of heterozygotes (0.63) with nearly similar gene frequency of both allele was also reported in Sahiwal based crossbred cattle 'Frieswal' (Bukhari et al., 2013). The minor differences observed in allele frequencies among studied Bos indicus breeds is in contrast to significant breed differences observed by Sharifi et al., (2010) in Najdi cattle and Alfonso et al., (2012) in American Swiss cattle. The significant departure $(\mathrm{p}<0.001)$ in gene and genotypic frequency from Hardy Weinberg equilibrium for exon-3 of $P R L$ gene as revealed through chi square statistics suggest the role of natural fitness in Bos indicus cattle for milk related traits (Mac-Hugh et al., 1997).

Table.1 Gene and genotypic frequencies of exon-3 of $P R L$ gene detected through RFLP analysis

\begin{tabular}{|c|c|c|c|c|c|c|c|c|c|}
\hline \multirow[t]{2}{*}{ Breed } & \multicolumn{3}{|c|}{ Genotypic frequencies } & \multicolumn{2}{|c|}{ Allele frequencies } & \multirow{2}{*}{$\begin{array}{l}\text { Std. } \\
\text { Error }\end{array}$} & \multirow[t]{2}{*}{$\mathrm{Chi}^{2}$} & \multirow{2}{*}{$\begin{array}{c}p \\
\text { value }\end{array}$} & \multirow{2}{*}{ Significance } \\
\hline & GG & $\mathrm{AG}$ & AA & G & A & & & & \\
\hline Rathi (75) & $\begin{array}{l}0.28 \\
(21)\end{array}$ & $\begin{array}{l}0.72 \\
(54)\end{array}$ & --- & 0.64 & 0.36 & 0.039 & 23.22 & 0.000 & ** \\
\hline $\begin{array}{c}\text { Sahiwal } \\
\text { (75) }\end{array}$ & $\begin{array}{l}0.19 \\
(14)\end{array}$ & $\begin{array}{l}0.81 \\
(61)\end{array}$ & --- & 0.59 & 0.41 & 0.040 & 34.58 & 0.000 & $* *$ \\
\hline $\begin{array}{c}\text { Kankrej } \\
\text { (75) }\end{array}$ & $\begin{array}{l}0.36 \\
(27)\end{array}$ & $\begin{array}{l}0.64 \\
(48)\end{array}$ & --- & 0.68 & 0.32 & 0.038 & 16.20 & 0.000 & $* *$ \\
\hline Overall & $\begin{array}{l}0.28 \\
(62)\end{array}$ & $\begin{array}{c}0.72 \\
(163)\end{array}$ & --- & 0.64 & 0.36 & 0.023 & 72.06 & 0.000 & ** \\
\hline
\end{tabular}


Table.2 List of position and nature of SNP's observed in exon-3 of PRL gene

\begin{tabular}{|c|l|l|l|}
\hline Base position & Region & Change & Nature of SNP's \\
\hline $\mathbf{3 9}$ & Coding & $\mathrm{C}>\mathrm{T}$ & Transition \\
\hline $\mathbf{5 8}$ & Coding & $\mathrm{C}>\mathrm{T}$ & Transition \\
\hline $\mathbf{5 9}$ & Coding & $\mathrm{C}>\mathrm{A}$ & Transversion \\
\hline $\mathbf{7 5}$ & Coding & $\mathrm{A}>\mathrm{G}$ & Transition \\
\hline
\end{tabular}

Table.3 Effect of genotypic patterns of exon-3 of $P R L$ gene on milk composition parameters

\begin{tabular}{|c|c|c|c|}
\hline \multirow[t]{2}{*}{ Breed } & \multicolumn{2}{|c|}{ Genotype } & \multirow[t]{2}{*}{ P- value } \\
\hline & GG & $\mathrm{AG}$ & \\
\hline \multicolumn{4}{|c|}{ Fat $(\%)$} \\
\hline Rathi (75) & $4.47 \pm 0.17$ & $4.55 \pm 0.11$ & 0.661 \\
\hline Sahiwal (75) & $4.43 \pm 0.12$ & $4.37 \pm 0.06$ & 0.669 \\
\hline Kankrej (75) & $4.50 \pm 0.12$ & $4.44 \pm 0.09$ & 0.865 \\
\hline Over all (225) & $4.46 \pm 0.08$ & $4.45 \pm 0.05$ & 0.945 \\
\hline \multicolumn{4}{|c|}{ Protein contents $(\%)$} \\
\hline Rathi (75) & $2.78^{\mathrm{a}} \pm 0.05$ & $2.93^{b} \pm 0.03$ & 0.022 \\
\hline Sahiwal (75) & $2.98^{\mathrm{a}} \pm 0.10$ & $3.23^{\mathrm{b}} \pm 0.05$ & 0.027 \\
\hline Kankrej (75) & $3.09^{\mathrm{a}} \pm 0.04$ & $3.21^{b} \pm 0.03$ & 0.023 \\
\hline Over all (225) & $2.96^{\mathrm{a}} \pm 0.04$ & $3.12^{\mathrm{b}} \pm 0.03$ & 0.001 \\
\hline \multicolumn{4}{|c|}{ Lactose (\%) } \\
\hline Rathi (75) & $4.75 \pm 0.16$ & $4.66 \pm 0.10$ & 0.647 \\
\hline Sahiwal (75) & $4.95 \pm 0.12$ & $4.73 \pm 0.06$ & 0.113 \\
\hline Kankrej (75) & $4.81 \pm 0.04$ & $4.79 \pm 0.03$ & 0.623 \\
\hline Over all (225) & $4.82 \pm 0.07$ & $4.72 \pm 0.04$ & 0.207 \\
\hline \multicolumn{4}{|c|}{ Solid not fat $(\%)$} \\
\hline Rathi (75) & $8.42 \pm 0.07$ & $8.51 \pm 0.04$ & 0.282 \\
\hline Sahiwal (75) & $8.80 \pm 0.10$ & $8.77 \pm 0.05$ & 0.824 \\
\hline Kankrej (75) & $8.80 \pm 0.05$ & $8.70 \pm 0.04$ & 0.080 \\
\hline Over all (225) & $8.67 \pm 0.04$ & $8.66 \pm 0.03$ & 0.846 \\
\hline \multicolumn{4}{|c|}{ Total solids $(\%)$} \\
\hline Rathi (75) & $16.61 \pm 0.52$ & $16.67 \pm 0.33$ & 0.924 \\
\hline Sahiwal (75) & $16.23 \pm 0.34$ & $16.15 \pm 0.16$ & 0.839 \\
\hline Kankrej (75) & $16.37 \pm 0.21$ & $16.15 \pm 0.16$ & 0.400 \\
\hline Over all (225) & $16.64 \pm 0.17$ & $16.50 \pm 0.10$ & 0.479 \\
\hline
\end{tabular}

Means in the same row bearing different superscripts are significantly different $(\mathrm{p}<0.05)$.

NS Non-significant 
Fig.1 Restriction fragment analysis of exon-3 of $P R L$ gene

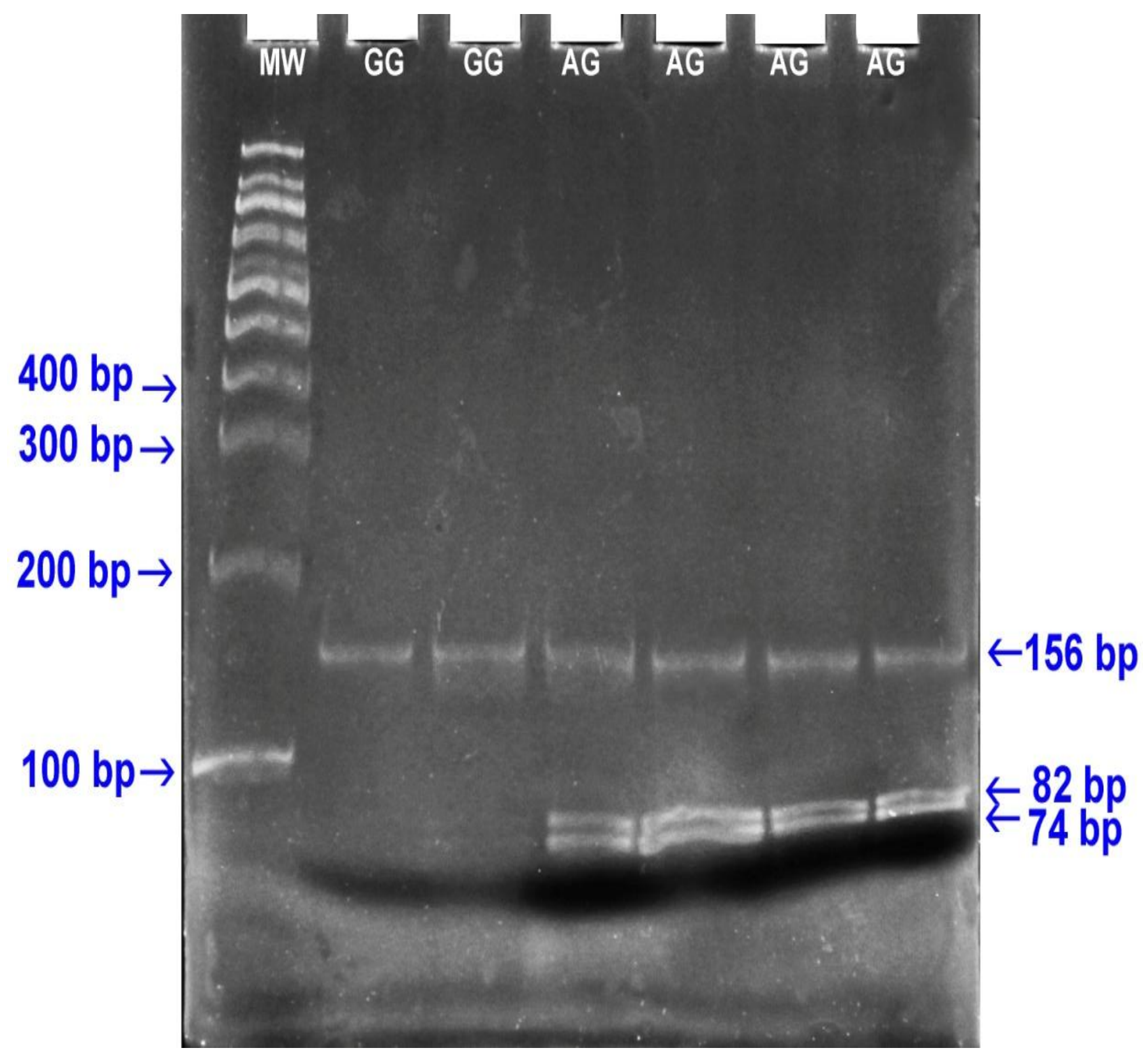

Lane 1: Molecular weight marker, Lane 2-3: genotype $G G$, Lane 4-7: genotype $A G$ 
Fig.2 Multiple sequence alignment of exon-3 of $P R L$ gene

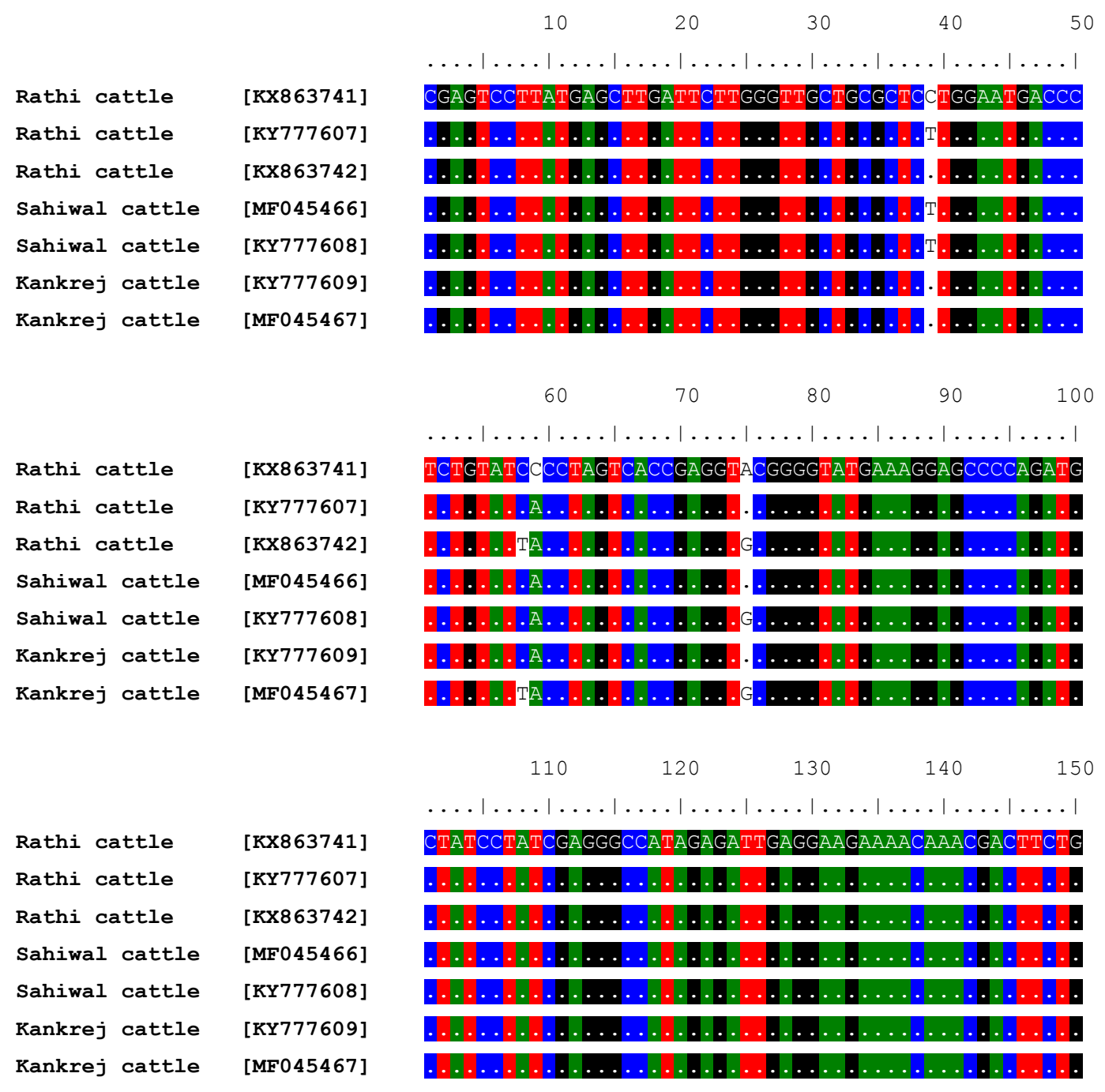

\begin{tabular}{|c|c|}
\hline Rathi cattle & [KX863741] \\
\hline Rathi cattle & [KY777607] \\
\hline Rathi cattle & [KX863742] \\
\hline Sahiwal cattle & [MF045466] \\
\hline Sahiwal cattle & [KY777608] \\
\hline Kankrej cattle & [KY777609] \\
\hline Kankrej cattle & [MF0 45467] \\
\hline
\end{tabular}

Similar absence of Hardy-Weinberg equilibrium was reported in two naturally adapted native Turkish breeds (Unal et al., 2015) and in American Swiss cattle (Alfonso et al., 2012). However, in contrast Ghasemi et al., (2009), Sharifi et al., (2010) observed non significant changes in gene and genotypic frequency in Montebeliard and Najdi cattle of 
Iran, respectively which could be due to breed differences or reduced number of analyzed samples $(\mathrm{n}<50)$, leading to poor and inefficient representation of different genotypes (Brym et al., 2005).Similar absence of Hardy-Weinberg equilibrium was reported in two naturally adapted native Turkish breeds (Unal et al., 2015) and in American Swiss cattle (Alfonso et al., 2012). However, in contrast Ghasemi et al., (2009), Sharifi et al., (2010) observed non significant changes in gene and genotypic frequency in Montebeliard and Najdi cattle of Iran, respectively which could be due to breed differences or reduced number of analyzed samples $(\mathrm{n}<50)$, leading to poor and inefficient representation of different genotypes (Brym et al., 2005).

The MSA and clustal analysis of accessioned sequences revealed that genetic variability contained in the different RFLP patterns of PRL gene in studied Bos indicus cattle were the result of substitution of four bases located at $39^{\text {th }}, 58^{\text {th }}, 59^{\text {th }}$ and $75^{\text {th }}$ position (Fig. 2). The SNP identified at $75^{\text {th }}$ position was responsible for the occurrence of restriction site in exon-3 of $P R L$ gene. The SNP's observed at $39^{\text {th }}, 58^{\text {th }}$ and $75^{\text {th }}$ positions were transition in nature whereas SNP detected at $59^{\text {th }}$ position was transverse mutation (Table 2). The current study reported less number of SNP's than Sasavage et al., (1974) and Kaminski et al., (2005) who identified seven and five SNP's, respectively in prolactin gene. The present study is in sharp agreement with the study conducted by Halabian et al., (2008) which reported four SNP's in a similar fragment of 156-bp in Iranian Holsteins cows of which two SNP's were reported to alter the predicted sequence of amino acids.

Analysis of milk composition for the three studied breeds revealed a similar nonsignificant impact of $R s a$ I alleles of $P R L$ exon-3 genes on milk fat in studied breeds
(Table 3) as observed by Alipanah et al., (2007b) in Red Pied cattle. In contrast, Chung and Kim (1997) reported higher milk fat for $G G$ and $A G$ genotypic pattern than $A A$ genotype. Significantly varied values of milk protein were observed for the detected restricted pattern of exon-3 of $P R L$ gene in all the studied Bos indicus breeds. The significantly higher milk protein detected for $A G$ genotype in each breed and on overall basis do suggest the specific role of A allele in enhancement of milk protein. Non significantly higher milk lactose was detected in animals having $G G$ genotype irrespective of the breed. The variation in SNF and total solid content of milk was also observed nonaffected with the two detected genotypic patterns in any of the breed. Very few studies have investigated the effect of $P R L$ genotypes on the milk composition traits. Similar to present investigation, results in Red Pied cattle showed that cows with $A A$ genotype had higher protein yield and but lesser fat $(\mathrm{p}<0.05)$ (Alipanah et al., 2008).

In conclusion, the detection of several polymorphic sites in the nucleotide sequence of the coding region of exon 3 of bovine $P R L$ gene in Bos indicus cattle in the present study create great possibility to use this genetic marker information for the genetic characterization of cattle populations for milk production traits and the sharing of polymorphism information on indigenous cattle genetic resources on national and global basis. The study concludes that heterozygotes genotypes for $P R L$ exon-3 gene were favored to produce milk containing adequate amount of protein.

\section{References}

Agrawal, V., Gahlot, G., Ashraf, M., Kumar, A. and Dhakad, G. 2018a. Genetic analysis of DGATI loci related to milk production traits in native Sahiwal cattle. International Journal of Livestock Research, 8(9): 136- 
142. doi: 10.5455/ijlr.20170928050917.

Agrawal, V., Gahlot, G., Ashraf, M., Thakur, S. and Gupta, S.R. 2018b. Molecular characterization of DGATlgene in Sahiwal cattle. Veterinary Practitioner. 19(2): 320322.

Anonymous. 2013. Breed Survey. Ministry of Agriculture and Farmers Welfare, Department of Animal Husbandry, Dairying and Fisheries, Government of India. Krishi Bhawan, New Delhi.

Alamer, M. 2011. The role of prolactin in thermoregulation and water balance during heat stress in domestic ruminants. Asian Journal of Animal and Veterinary Advances. 1-17. doi: 10.3923/ajava.2011.

Alfonso, E., Rojas, R., Herrera, J.G., Ortega, M.E., Lemus, C., Cortez, C., Ruiz, J., Pinto, R. and Gomez, H. 2012. Polymorphism of the prolactin gene $(P R L)$ and its relationship with milk production in American Swiss cattle. African Journal of Biotechnology. 11: 7338-7343.

Alipanah, M., Kalashnikova, L. and Rodionov, G. 2007a. Association of prolactin gene variants with milk production traits in Russian Red Pied cattle. Iranian Journal of Biotechnology. 5: 158-161.

Alipanah, M., Kalashnikova, L.A. and Rodionov, G.V. 2007b. Polymorphism prolactin loci in Russian cattle. Journal of Animal and Veterinary Advances. 6(6): 813-815.

Alipanah, M., Alexandrovna, K. and Rodionov, G.V. 2008. Kappa-casein and PRL-RsaI genotypic frequencies in two Russian cattle breeds. Archivos de Zootecnia. 57: 131138.

Aravindakshan, T.V., Venkatachalapathy, R.T., James, S.P., Kurien, E. and Iype, S. 2004. Polymorphism of the prolactin gene locus in Vechur and other dwarf (Kassargode) cattle of Kerala detected by PCR-RFLP. Indian Journal of Dairy Science. 57(4): 246-249.

Bennewitz, J., Reinsch, N., Paul, S., Looft, C., Kaupe, B., Weimann, C., Erhardt, G., Thaller, G., Ku, C.H., Schwerin, M., Thomsen, H., Reinhardt, F., Reents, R. and Kalm, E. 2004. The DGAT1 K232A mutation is not solely responsible for the milk production quantitative trait locus on the bovine chromosome 14. Journal of Dairy Sciences. 87: 431-442.

Brym, P., Kaminski, S. and Wojcik, E. 2005. Nucleotide sequence polymorphism within exon 4 of the bovine prolactin gene and its associations with milk performance traits. Journal of Applied Genetics. 45: 179-185.

Bukhari, S., Khan, N.N., Gupta, P., Das, A.A., Raher, G.A., Chakraborty, D. and Pandey, A. 2013. Prolactin gene polymorphism and its associations with milk production traits in Frieswal cow. International Journal of Molecular Zoology. 3(3): 10-13.

Charoenphandhu, N. and Krishnamra, N. 2007. Prolactin is an important regulator of intestinal calcium transport. Canadian Journal of Physiology and Pharmacology. 85(6): 569-81.

Dong, C.H., Song, X.M., Zhang, L., Jiang, J.F., Zhou, J.P. and Jiang, Y.Q. 2013. New insights into the prolactin-RsaI (PRL-RsaI) locus in Chinese Holstein cows and its effect on milk performance traits. Genetics and Molecular Research. 12(4): 5766-5773.

El-Magd, M.A., Abbas, H.E., El-kattawy, A.M. and Mokhbatly, A. 2013. Novel polymorphisms of the IGF1R gene and their association with average daily gain in Egyptian buffalo (Bubalus bubalis). Domestic Animal Endocrinology. 45: 105110.

Ghasemi, N., Zadehrahmani, M., Rahimi, G. and Hafezian, S.H. 2009. Associations between prolactin gene polymorphism and milk production in Montebeliard cows. International Journal of Genetics and Molecular Biology. 1(3): 48-51.

Halabian, R., Nasab, M.P.E., Nassary, M.R., Mossavi, A.R.H., Hosseini, S.A. and Qanbari, S. 2008. Characterization of SNPs of bovine prolactin gene of Holstein cattle. Biotechnology. 7(1): 118-123.

Hu, X., Lu, A., Chen, H., Gao, X., Xu, H., Zhang, C., Fang, X. and Lei, C. 2009. Preliminary evidence for association of prolactin and prolactin receptor genes with milk production traits in Chinese Holsteins. Journal of Applied Animal Research. 36(2): 213-217.

doi: 10.1080/09712119.2009.9707062.

Kaminski, S., Ahman, A., Ruse, A., Wojcik, E. 
and Nualewski, T. 2005. MilkProtChip-a microarray of SNPs in candidate genes associated with milk protein biosynthesisdevelopment and validation. Journal of Applied Genetics. 46: 45-58.

Komisarek, J. and Dorynek, Z. 2009. Effect of ABCG2, PPARGC1A, OLR1 and SCD1 gene polymorphism on estimated breeding values for functional and production traits in Polish Holstein-Friesian bulls. Journal of Applied Genetics. 50: 125-132.

Krovvidi, S., Panneerselvam, S., Thiruvenkadan, A.K., Abraham, J. and Kumar, V. 2013. Factors effecting milk composition of crossbred dairy cattle in Southern India. International Journal of Food, Agriculture and Veterinary Science. 3(1): 229-233.

Kumari, A.R., Singh, K.M., Soni, K.J., Chauhan, J.B., Patel, R.K, and Sambasiva-Rao, K.S.R. 2008. Genotyping of polymorphism within exon 3 of prolactin gene in various dairy breeds by PCR RFLP. Journal of Animal Breeding. 51(3): 298- 299.

Mac-Hugh, D.E., Shriver, M.D., Loftus, R.T., Cunningham, P. and Bradley, D.G. 1997. Microsatellite DNA variation and the evolution, domestication and phylogeography of Taurine and Zebu cattle (Bos taurus and Bos indicus). Genetics. 146: 1071-1086.

Mitra, A., Schlee, P., Balakrishnan, C.R. and Pirchner, F. 1995. Polymorphisms at growth hormone and prolactin loci in Indian cattle and buffalo. Journal of Animal Breeding and Genetics. 112: 71-74.

Mohammed, S.A., Rahamtalla, S.A., Ahmed, S.S., Elhafiz, A., Dousa, B.M., Elamin, K.M. and
Ahmed, M.K.A. 2015. DGAT1 gene in dairy cattle. Global Journal of Animal Scientific Research. 3(1): 191-198.

Othman, O.E., Zayed, F.A., Ali, A.E., Gawead, B. and El-Rahman, M.R.A. 2011. Genetic polymorphism of three genes associated with milk trait in Egyptian buffalo. Journal of Genetic Engineering and Biotechnology. 9: 97-102.

Sacravarty, G., Vadodaria, V.P., Joshi, C.G., Brahmkshtri, B.P., Shah, R.R. and Solanki, J.V. 2008. Prolactin gene polymorphism and its association with economic traits in Kankrej cattle. Indian Journal of Dairy Science. 61 (4): 273-76.

Sasavage, N.L., Nilsson, J.H., Horowitz, S. and Rotman, F.M. 1974. Nucleotide sequence of bovine PRL-Rsa I messenger RNA. Journal of Biological Chemistry. 24: 678681.

Sharifi, S., Roshanfekr, H., Khatami, S.R. and Mirzadeh, K.H. 2010. Prolactin genotyping of Najdi cattle breed using PCR-RFLP. Journal of Animal and Veterinary Advances. 9: 281-283.

Udina, I., Turkova, S., Kostuchenko, M., Lebedeva, L. and Sulimova, G. 2001. Polymorphism of bovine prolactin gene, microsatellites, PCR-RFLP. Russian Journal of Genetics. 4: 407-411.

Unal, E.O., Kepenek, E.S., Dinc, H., Ozer, F., Sonmez, G., Togan, I.J. and Soysal, M.I. 2015. Growth hormone $(G H)$, prolactin $(P R L)$, and diacylglycerol acyltransferase (DGAT1) gene polymorphisms in Turkish native cattle breeds. Turkish Journal of Zoology. 39: 734-748.

\section{How to cite this article:}

Vijay Kumar Agrawal, Gyanchand Gahlot1, Rajeev Joshi, Govind Singh Dhakad and Sonal Thakur. 2020. Assessment of Genetic Variability in Prolactin Gene and Its Impact on Milk Composition in Bos indicus Cattle. Int.J.Curr.Microbiol.App.Sci. 9(06): 1514-1524. doi: https://doi.org/10.20546/ijcmas.2020.906.187 